\title{
A Primer on the Government and Politics of Poland
}

\author{
Richard J. Hunter, Jr. \\ Stillman School of Business, Seton Hall University \\ 400 South Orange Avenue, South Orange, N.J., U.S.A \\ E-mail hunterri@shu.edu
}

The research is supported by the Institute for International Business, Seton Hall University

\section{Abstract}

Poland engaged in a "self-limiting" revolution in 1989 in which it began a process of changing both its economic and its political systems. In this context, governmental and party politics came to the forefront in efforts to effect real change in society as the "closed" communist system came to an abrupt end. This paper is a study of governmental structures and party politics in Poland as they relate to these changes. It discusses the Polish legislative, presidential (executive), and judicial systems and the current political configurations operating within Poland. The author offers commentary on what the future may hold for politics in a nation still struggling to define its role in the European Union in light of its most recent past.

Keywords: Government; Sejm; Politics; Law and Justice; Civic Platform

DOI: $10.7176 / \mathrm{EJBM} / 12-5-01$

Publication date: February $29^{\text {th }} 2020$

\section{Part I - Governmental Structure}

\section{Introduction}

Over these past thirty-five years, I have joined with several of my colleagues at Seton Hall University and elsewhere to write about various aspects of Polish economics, taxation, society, finance, and politics. [See Appendix I for full chronological bibliographic references.] Part I of this primer will focus on the governmental structure of Poland. Part II will focus on Poland's current political configurations and groupings. In conclusion, I will provide commentary on the future of politics in Poland.

\section{Governmental Structures}

The government of Poland may be viewed from the perspective of a "unitary semi-presidential representative democratic-republic" governed by both a President (Polish: Prezydent Rzeczypospolitej Polskiej, shorter form, Prezydent RP) and a Prime Minister (Polish: Prezes Rady Ministrów). The President of Poland is the Head of State and the Prime Minister is the Head of Government. At present, the President is Andrzej Duda, elected in 2015, and the Prime Minister is Mateusz Morawiecki, who took office in 2017.

Executive power is exercised in Poland within the framework of a multi-party political system by the President and the government, which consists of the Council of Ministers (Polish: Rada Ministrów Rzeczypospolitej Polskiej) (similar to the Cabinet in the U.S. system), led by the Prime Minister. The members of the Council of Ministers are typically chosen from the majority party or governing coalition in the lower house of parliament (Polish: the Sejm), although there may be exceptions under Poland's rather unique governmental system. The government is formally announced by the President, and must pass a motion of confidence (considered as an approval) in the Sejm within two weeks of the conclusion of a parliamentary election in order to take office.

Legislative power is vested in the two chambers of Parliament (Marchuk, 2018): the Sejm, consisting of 460 members elected in multi-person districts and presided over by a speaker called the "Marshal of the Sejm of the Republic of Poland" (Polish: Marszatek Sejmu Rzeczypospolitej Polskiej), and a one hundred-member Senate (Polish: Senat). Since 1991, elections in Poland are supervised by the National Electoral Commission (Polish: Państwowa Komisja Wyborcza), whose administrative division is called the National Electoral Office (Polish: Krajowe Biuro Wyborcze).

Election for the Sejm is through "open party-list proportional representation" in multi-seat constituencies, with a $5 \%$ national threshold for single parties and an $8 \%$ threshold for party coalitions (requirements may be waived for specially designated "ethnic minorities," although it should be recognized that Poland is one of the most homogeneous countries in the world, with $97 \%$ of its population being "ethnic" Polish). The major ethnic minority groups recognized by the Polish government are German, Belorussian, Ukrainian, Lemko, Roma, and ethnic Jews. 39.5\% of the ethnic minorities live in the Silesian Voivodship, $28.3 \%$ in the Opolskie Voivodship, and $11.7 \%$ in the Podlaskie Voivodship. (A Voidvodship is an administrative region or province of Poland, governed by a Voivode, a position similar to that of a Governor. Poland is divided in 16 provinces or Voivodeships (Polish: województwa, singular - województwo): Lower Silesia, Kuyavia-Pomerania, Łódź, Lubelskie, Lubusz, Lesser Poland, Masovia, Opole, Subcarpathia, Podlaskie, Pomerania, Silesia, Świętokrzyskie, Warmia-Masuria, Greater Poland, and West Pomerania.) 
At present, the following standing committees exist in the Sejm which are responsible for preparing legislation under the direction of the Prime Minister:

- Administration and Internal Affairs

- Agriculture and Rural Development

- Liaison with Poles Abroad

- Constitutional Accountability

- Culture and Media

- Deputies' Ethics

- Economic Committee

- Education, Science and Youth

- Enterprise Development

- Environment Protection, Natural Resources and Forestry

- European Union Affairs

- Family and Women Rights

- Foreign Affairs

- Health

- Infrastructure

- Justice and Human Rights

- Legislative

- Local Self-Government and Regional Policy

- National and Ethnic Minorities

- National Defense

- Physical Education and Sport

- Public Finances

- Rules and Deputies' Affairs

- Social Policy

- Special Services

- State Control

- State Treasury

- Work

The Senate is elected using "first-past-the-post voting" (or "winner-take-all") in single-member districts. To be included on a ballot, a candidate for the Senate must present 2,000 valid signatures of support from their constituents. For elections to the Sejm, the threshold is 5,000 signatures per electoral constituency. This requirement is waived for parties that have already registered lists in at least half of all constituencies ( 21 out of 41, as of the 2019 parliamentary elections).

Members of the Sejm are elected in a system of proportional representation. Currently five political parties are represented in the Sejm: PiS-235 seats; PO-134 seats; Left -49 seats; Polish Coalition-30 seats; Confederation - 11 seats; and the German Minority - 1 seat. Parliamentary elections occur at least every four years, unless the Sejm is dissolved and early elections are called.

The President of Poland is the Head of State. Under the Polish Constitution of 1997 (Granat \& Granat, 2019), the President is the supreme commander of the Armed Forces. As such, the President appoints the Chief of the General Staff (Polish: Szef Sztabu Generalnego Wojska Polskiego) and commanders of the branches of the Armed Forces. The Armed Forces of the Republic of Poland (Polish: Sity Zbrojne Rzeczypospolitej Polskiej, abbreviated SZ RP; popularly called Wojsko Polskie in Poland, abbreviated WP-roughly, the "Polish Military") are the Wojska Ladowe (Polish Land Forces), Marynarka Wojenna (Polish Navy), Sity Powietrzne (Polish Air Forces), Wojska Specjalne (Polish Special Forces) and Wojska Obrony Terytorialnej (Polish Territorial Defense Force) which are under the command of the Ministerstwo Obrony Narodowej Rzeczypospolitej Polskiej (Ministry of National Defense of Poland).

The President has the power to veto legislation passed by parliament, which then may be overridden by a three-fifths majority of both houses of the Parliament. The President can dissolve the parliament under certain conditions specified in the Constitution.

The President, as the representative of the Polish state in foreign affairs, has the authority to ratify and renounce international agreements, appoint and recall the plenipotentiary (diplomatic) representatives of the Republic of Poland, and is required to cooperate with the Prime Minister and the appropriate minister in respect to matters relating to foreign policy.

Under certain circumstances, the President may convene a body called the Cabinet Council, although the Cabinet Council does not possess the competence or powers of the Council of Ministers. Official acts of the President require the signature (effectively the concurrence) of the Prime Minister for their validity. However, the signature of the Prime Minister is not required under the following circumstances: 
1. Nominating and appointing the Prime Minister;

2. Shortening of the term of office of the Sejm in the instances specified in the Constitution;

3. Introducing legislation;

4. Requesting the Sejm to appoint the President of the National Bank of Poland;

5. Appointing judges

6. Proclaiming the holding of a nationwide referendum (however, consent of the Senate is required to do so);

7. Signing or refusing to sign a bill;

8. Exercising the power of pardon; and

9. Convening the Cabinet Council.

In addition, the concurrence of the Prime Minister was not required in appointing the first President of the Supreme

Court, the President of the Constitutional Tribunal, members of the Council for Monetary Policy, or appointing and dismissing members of the National Security Council.

Presidential elections occur every five years. The President is elected by a majority of voters. However, if no candidate receives the required majority in a first round of voting, the top two candidates will participate in a second round or runoff election.

The political system is defined in the Polish Constitution, the most recent of which was adopted in 1997. The Constitution guarantees a wide range of individual freedoms and rights to Polish citizens. An important part of the judicial branch is the Constitutional Tribunal.

The Constitutional Tribunal (Polish: Trybunat Konstytucyjny) is the constitutional court of the Republic of Poland. The Constitutional Tribunal was established to resolve disputes concerning the constitutionality of the activities of state institutions and to supervise the compliance of statutory law with the Constitution.

When sitting in a joint legislative session, members of the Sejm and Senate form the National Assembly (Polish: Zgromadzenie Narodowe). The National Assembly is constituted on three occasions: taking the oath of office by a new President; bringing an indictment against the President of the Republic to the Tribunal of State; and the necessity of the declaration of a President's permanent incapacity to exercise their duties due to the state of their health.

\section{Part II - A Brief Précis of Polish Politics \\ 3. Polish Politics}

Since 1989, Poland has operated under a multi-party political system. Individual parties have traditionally worked with other parties to form electoral coalitions. Before initiating a discussion of the major political parties and configurations operating in Poland today, a discussion of some general background is in order (generally Pronczuk, 2019).

The political transition from a centralized mono-party communist regime dominated by the Polish United Workers (or Communist) Party (Sulek, 2007; Ostrowski, 2019) and several of its smaller counterparts to a "liberal democracy," decentralization (Sakowitz, 2017), and political pluralism resulted in new political parties literally mushrooming in the early 1990s (Lewis, 2007). In fact, as Millard (1994) noted: "The first fully competitive parliamentary elections in 1991 confirmed this fragmentation, as deputies from twenty-nine electoral committees took their seats in the Lower House." (Most interesting among the new competitors was the Polish Beer-Lovers' Party (Poland: Polska Partia Przyjaciót Piwa), led by a popular comedy actor, Janusz Rewinski, of which the author joined as an honorary, yet somehow dues paying member!). The existence of a plethora of parties in the Sejm was seen by many as counterproductive to the effectiveness of the parliamentary system, as an impediment to producing stable, sustainable governments, and to a veritable parade of Polish Prime Ministers. [See Appendix II for a list of the Prime Ministers of Poland since 1989.]

As a result, "electoral reform" was undertaken and an electoral threshold for the Sejm was instituted prior to the 1993 elections. The threshold for representation in the Sejm was set at a minimum vote of 5\% for parties (with exemptions for ethnic minority parties) and $8 \%$ for electoral coalitions. The threshold was set at the national, rather than at individual district levels. As a result, many minor parties and independent candidates failed to win election in the 1993 parliamentary elections and in later elections as well.

Fundamental and far reaching economic and political changes were initiated post-1989 period, which on the economic side were referred to as "shock therapy." Marvin (2010) describes these changes initiated under the "Balcerowicz Plan" (Hunter \& Ryan, 2009) as:

"a drastic neoliberal package of liberalizing economic reforms that Poland quickly adopted as it emerged from Soviet domination. While shock therapy was an effective response to communist Poland's economic deadlock, it did come with high short term costs that could have been avoided. Poland's transition to the market economy after its political liberalization in 1989 is generally regarded as one of the most successful transitions of all post-Soviet economies. Despite its 
unnecessarily rushed introduction, shock therapy was successful because it was the right policy set at the right time for Poland."

The program was based on five philosophical pillars of economic transformation:

- Rapid transformation of the monocentric system of state central planning into a private functioning market economy;

- Liberalization of economic functions, especially in relation to foreign trade and foreign direct investment;

- Privatization of state-owned-enterprises (SOEs);

- $\quad$ Construction of an effective social safety net; and

- Mobilization of international financial assistance to support the process.

Fafara and Kleczkowska $(2015$, p. 60) point out that the Balcerowicz Plan was an "ambitious process that enabled a significant shift in the economic and social landscape through the introduction of fundamental changes in the Polish legal system." They describe the eleven legislative acts which brought "wide ranging and fundamental changes to the Polish legal system" and make a more general point that "successful transformation of the state's regime in post-soviet countries depended not only on political changes, but also on effective economic reforms."

Yet, Marvin (2010) continues: "The economic revolution sparked a deep and unanticipated recession that the architects of shock therapy were not prepared to address." The economic uncertainty and even turmoil experienced in society certainly spilled over into Polish politics.

\section{1 "Left" versus "Center Right" versus "Right"}

On the political side, the "left side" of the political scene in Poland has generally been dominated by former members of the communist party, who have now embraced the philosophy of traditional Western European social democrats. [Social democracy may be defined as a "political, social and economic philosophy that supports economic and social interventions to promote social justice within the framework of a liberal democratic policy and a capitalist-oriented economy" (see generally Dorrien, 2019)].

Also, since the early 1990's, the political "right" has been largely comprised of former Solidarity activists and its supporters (Hunter \& Lozada, 2019). However, almost from the outset (perhaps stemming from the "War at the Top" which occurred between the supporters of Solidarity hero, Lech Walesa (Engelberg, 1990), and the supporters of the Prime Minister Tadeusz Mazowiecki in the Presidential elections of 1990), post-Solidarity parties on the political "right" have certainly experienced deep fissures and divisions and a lack of cohesiveness and have on occasion merged, split, be renamed, and repurposed with the vagaries of Polish politics and economics. Perhaps due to the weakness or unpopularity or collapse of the "left," parties of the "right" did manage to win parliamentary elections from 1997-2001, having initially governed from 1989-1993.

Following the parliamentary elections of 2005, parties on the right have certainly dominated the political scene. Two important developments in the political landscape may account for this dominance. First, the SLD or Democratic Left Alliance (Polish: Sojusz Lewica Demokratycznej) is no longer a major political player in Poland. Second, the main political battleground in Poland now stands between the ex-Solidarity "hard-right" versus the more "center-right." However, Solidarity (Polish: Solidarnosc), as an independent political party, has virtually disappeared from the Polish political scene (Hunter \& Lozada, 2019).

The new competing groupings in Poland today on the "right" and "center-right" are Law and Justice (Polish: Prawo i Sprawiedliwość), or PiS, which generally promotes economic interventionism and redistributionism (Rzegocki \& Partyka, 2017) by the state, coupled with deep social conservatism; and Civic Platform (Polish: Platforma Obywatelska), or PO, which has been characterized as "representing a more liberal-conservative position" (see Gabryszak, 2019). Perhaps this obvious internal inconsistency of combining terms such as "liberal" and "conservative" as a foundation of party policy has led to some confusion and to a general belief that the PO is more well-known for its opposition to the policies of PiS rather than any fundamental policy perspectives of its own.

The following is a more detailed look

\subsection{Law and Justice (PiS)}

PiS was successful in the 2015 parliamentary elections pledging to "bring Poland up from its knees" and "give back dignity to the people" (Pronczuk, 2019). PiS finds its core base in eastern Poland "among small, pious farmers and working-class families who have lost jobs and income through the change from a state economy to an often ruthless neoliberalism" (Ascherson, 2016).

The policies of PiS have been subjected to withering criticisms. "Almost immediately, the PiS introduced a series of supposed "judicial reforms" which were heavily criticized by Brussels ("The European Union") and the PO. Opponents characterized proposals as an attempt to limit the judiciary's independence," stated Scislowska (2017). Ascherson (2016) noted that "Law and Justice has ... packed the Constitutional Court, politicized the appointment of prosecutors, abolished court consent for state access to private internet accounts and brought public 
broadcasting under direct government control." Kovacs and Scheppele (2018) point out "the constitutional courts and then the ordinary judiciary have been brought under the control of political forces so that there is no longer a separation of law and politics." Chapman (2017) weighs in on issues relating to press freedom and notes:

- "Poland has become a crucial battleground in the drive by authoritarian-minded leaders to gain control over political discourse and limit media pluralism."

- "The Law and Justice government has sought to control the media as part of a broader push to weaken checks and balances and silence independent voices. By rejecting the media's independence, the government is deepening polarization within Poland."

- "The fate of media freedom in Poland will herald either the continued march of populist authoritarianism around the world or a turning of the tide and a new period of democratic resilience."

- "The EU and Poland's allies, including the United States, should make clear that Poland's best interests lie in respecting the media's independence and allowing a diversity of views to flourish."

Supporters of PiS vehemently disagree.

Jarosław Kaczyński, who had served as Prime Minister in 2006-2007, became the literal "face of the PiS" in 2010, following the tragic death of his twin brother, Lech Kaczyński, in the Smolensk plane crash (Hunter, 2010). Lech Kaczynski, a former mayor of Warsaw, was at the time of his death the elected President of Poland (Sleszynski, 2006; Hunter, 2010). Observers note that while Jarosław Kaczyński does not hold any office or perform any official state function, he is the de facto leader of the country, exercising great influence on the government's personnel and policies (Ascherson, 2016). As noted by Kosicki (2016), "He rose to power briefly a decade ago, promising to create a 'Fourth Republic,' to elevate the Catholic Church's position in public life, to reinstitute Communist-era welfare guarantees, and-most provocatively - to expose the alleged skeletons in the closets of the Third Republic's political and business elites."

PiS captured the Presidency in 2016 when PiS candidate Andrzej Duda surprisingly upset the incumbent Bronislaw Komorowski (Casey, 2015), who had, as Marshall of the Sejm, succeeded Lech Kaczynski upon his death. The current Prime Minister is Mateusz Morawiecki, the son of a well-known and respected Solidarity activist, Kornel Morawiecki, also from the PiS. PiS combines nationalism with social conservatism and enjoys the support of the powerful Polish Roman Catholic Church. Ramet (2016) notes that "the Church has taken advantage of the fall of communism to push its own social agenda, at times against the wishes of most Poles." Zuk and Zuk (2019) also note the "growing gap between the clerical state and the increasingly secularized society."

PiS essentially supports a policy of "social redistribution" (Rzegocki \& Partyka, 2017), including the introduction of a generous universal child-benefit program, seemingly recognizing Poland's twin crises of low fertility and "mass emigration to other Western countries." PiS stands as a self-described defender of Poland's sovereignty, culture, values, and Catholic faith against various foreign and domestic enemies (see Zuk \& Zuk, 2019), including refugees, the LGBT community (Roache, 2019), political correctness, and the European Union. On the economic front, PiS has lowered the retirement age, which had been raised by the previous PO government in an attempt to shore-up Poland's retirement regime, and instead has provided additional payments to Polish pensioners. It has strong links with the Polish Roman Catholic Church (Zuk \& Zuk, 2019), still a very influential institution in Poland, which exhibited a considerable clout in parliamentary elections from 1989 through 2010 and beyond (Kowalczyk, 2012). PiS continues to defend the coal-dependent Polish energy sector-as much as $81 \%$ of Poland's electricity comes from coal (Sauer, 2018) - currying the favor (and votes) of heavily subsidized miners (Sauer, 2018) and others employed in the mining sector.

In foreign policy, PiS is staunchly "anti-Russian" and favors strengthening and expanding political and economic ties with the United States (King, 2017), which it sees as the primary guarantor of Poland's military security against Russia. Balcer, Buras, Gromadzki, and Smolar (2016, p. 2) write that "The most significant element of Poland's foreign policy paradigm redefinition by PiS is based on a deep pessimism as regards the future of European integration" and sees foreign policy clearly as "secondary to domestic objectives." Recently, PiS has enthusiastically endorsed the placement of an American military installation in Poland, which it has dubbed "Fort Trump." It ranks as one of its major achievements ending the visa requirement for Polish citizens who wish to visit the United States as further proof of its close relationship with the United States and President Trump. As noted by Taylor (2018): "The White House calls the move an 'important step in continuing to increase economic, security, cultural, and people-to-people connections between our two nations.' Poland has pursued access to the program for decades, and with the announcement of its nominations, it looks as though it will finally be included."

On the economic front, PiS has promised to raise Poland's minimum wage to 4,000 zloty a month by 2023 (approximately \$1,000), almost doubling the present figure, and to provide two "extra" monthly pension payments to Polish retirees (Harper, 2019). PiS also pledged to protect the traditional family model and "Catholic values," to continue its reforms of the Polish judiciary, and also promised to "re-Polonise" and "take back control" of the media after its victory in last fall's parliamentary elections, in which PiS received $43.59 \%$ of votes-a higher percentage than any individual party has achieved in the entire post-communist period. This translated into 235 seats, the same number as it had won in 2015. Because it had achieved a majority in the Sejm, PiS was able to 
form a government without seeking the concurrence of any other parties or groupings in a coalition government. However, PiS does not have enough of a majority to seek to change the constitution on its own right, which would require a two-thirds majority in the Sejm. Surprisingly, in the fall parliamentary elections, PiS actually lost its previous majority in the Senate, winning 48 seats, with the number of opposition and opposition-aligned independent senators amounting to 52.

In actuality, however, PiS governs Poland at the senior-partner in an informal conservative coalition, known as the United Right (Polish: Zjednoczona Prawica), formed between PiS, United Poland (Polish: Solidarna Polska), and the Agreement (Polish: Porozumienie), two smaller right-wing parties.

\subsection{Civic Coalition: Civic Platform (PO)}

PO is a center-right party, which governed Poland between 2007 and 2015. PO was formerly under the leadership of Donald Tusk, who left Polish electoral politics in 2014 to become the President of the European Council (Lykoshina, 2015). Recently, Tusk announced that he would not be a candidate in Poland's next Presidential election, acknowledging that he had accumulated "too much baggage" to be a viable candidate (Cienski, 2019).

Interestingly, despite their more recent very public feuding, PO's origins closely track those of PIS and can be traced to the political groupings in the immediate post-Solidarity period. Kaczynski and his allies have accused PO of being a part of the "post-communist establishment" that had exploited Poland's transition, sacrificing the interests of ordinary Poles to alien values, and to the whims of the former nomenklatura and foreign business interests. In opposition to PiS, PO has moved more towards the center in Polish politics and represents a more traditional liberal economic position, supporting low taxes and individual entrepreneurship, the "rule of law" (Krygier, 2017), faith in the free market, and opposition to unnecessary government intervention in the economy. PO has incurred the wrath of more conservative Poles and the Roman Catholic Church, as it has adopted a moderately conservative approach on social issues. Abortion continues to be a flashpoint in Polish society and politics.

PO supports Poland's existing abortion "compromise," vigorously opposed by the Catholic Church, which has adopted an absolute opposition to all forms of abortion (Mishtal, 2015; Szelewa, 2016; Hussein, Cottingham, Nowicka, \& Kismodi, 2018). (Abortion is illegal in Poland except in cases of rape, when the woman's life or health is in jeopardy, or if the fetus is irreparably damaged.) Despite being labeled as "liberal" by its conservative detractors, the current law is among the strictest laws in the European Union. PO has also announced limited support for same-sex civil unions, diversity, LGBT rights (O’Dwyer \& Vermeersch, 2016), an independent media, and the environment.

PO's junior parliamentary partner, Modern (Polish: Nowoczesna) may be considered as a traditional "liberal" party that was created in 2015 by former World Bank economist Ryszard Petru. Petru was replaced by current leader Professor Katarzyna Lubnauer. Modern likewise supports both liberal economic and social policies, but is now very much the junior partner in its coalition with PO.

In reaction to PiS, PO has promised to "restore democracy and the rule of law," as well as promoting further European integration and respect for the "fundamental values of the European Union" (Hunter \& Domanska, 2016; Wyrzykowski, 2018). It also promises to overturn the Sunday trading and shopping ban introduced by PiS (Underwood, 2017) and to restore state funding for IVF (in vitro fertilization) procedures, which was ended by PiS. PO has also pledged to eliminate coal from Poland's energy mix by 2040 as part of its pro-environment agenda.

In last fall's parliamentary elections, PO garnered $27.4 \%$ of votes, giving them 134 seats in the Sejm, although in elections to the Senate, PO won 43 seats in its own right and joined with other opposition parties, with whom PO had made a pact not to stand against one another, winning an additional five seats. Four senators were elected as "officially independent." The Senate has the power to delay (but not to defeat) legislation enacted by the Sejm and to make it much harder for PiS to implement its more controversial changes through the legislative process.

PO has suffered five successive election defeats since the start of 2015 (see Grabowski, 2019). There is a strong sense that PO has struggled to find a clear and consistent policy narrative since 2015 and is more widely known for the opposition to policies of PiS rather than for its own legislative proposals and agenda.

\subsection{The Left}

Following the failure of the Polish "left" to win any representation in parliament in the 2015 elections (generally, Kosicki, 2016), Poland's three main left-wing parties chose to stand together in the 1999 parliamentary elections, ensuring they would pass the $8 \%$ electoral threshold.

The Democratic Left Alliance (Polish: Sojusz Lewica Demokratycznej), or SLD, is today a centre-left party with many of its founders and some of its supporters tracing their roots to Poland's former communist party. SLD actually achieved success in a "landslide victory" in the first completely free parliamentary elections of 1993 (Chan, K.K-L. (2007), and into the 1990s (March 1995-October 1997), and again from October of 2001 through October of 2005, when many Polish voters expressed their dissatisfaction with the nature and speed of promised reforms. [The same situation seems to have occurred in many of the former communist countries in Central and Eastern 
Europe (Grzymala-Busse, 2002)]. SLD capitalized on the frustration of many Polish workers who has formed the backbone of the Solidarity movement, but who had reached what was termed as the "barrier of social endurance" (Hunter \& Ryan, 1998, p. 9). Its open former-communist standard-bearer, Aleksander Kwasniewski, defeated Solidarity hero Lech Walesa in his bid for re-election to the Polish presidency in 1995, but largely governed Poland in a decidedly non-ideological basis.

One of SLD's partners, Spring (Polish: Wiosna), was recently established by Robert Biedroń, a former mayor of Slupsk, and an open LGBT rights activist. Wiosna won 6\% of the vote and three seats in the European Parliament in the elections for Polish representation in Brussels.

A second grouping, Together (Polish: Razem), has been described by some observers as "the new left" in Poland, completely separate from any post-communist heritage. Lacking strong leadership, Razem failed to pass the 5\% electoral threshold on its own, forcing it into its current alliance with SLD and other coalition partners.

SLD ran on a platform decidedly to the left of the PO coalition (and certainly to the left of PiS), promising significant liberalization on the social front, including limiting Poland's strict abortion law; improving access to contraception and sex education; and strengthening LBGT rights, including eventually introducing same-sex marriage. In keeping with its core "left" principles, SLD also pledged to expand social services by providing free nurseries, free meals for children at schools, and free public transport for the elderly.

To the surprise of many observers, the SLD coalition received $12.56 \%$ of votes in the parliamentary elections, which translated into 49 seats in the Sejm. The SLD claimed that the result constituted a significant victory, considering the fact that both the SLD and Together had failed to pass the $5 \%$ threshold in the previous parliamentary elections, and did not win any seats in the lower house or Sejm.

Reports indicate that SLD and Wiosna are currently planning to merge into a single parliamentary caucus, adopting yet another new name, unknown at this date. Whatever structure eventually materializes, the "new left" consists of many "young, new faces" which hopes will attract Poles who have grown exhausted by continuing the infighting of Poland's most recent thirty-year past, advocating socially liberal policies and offering a decided alternative to PiS's redistributionist policies, to which the opposition struggled to respond during the last parliamentary elections. Could the "left" actually make a comeback in Polish politics? Zuk (2017) doubts that the "left" will play any real important role in Polish politics and has dubbed its future success as a "non-alternative reality."

\subsection{Other Parties and Groupings}

There are several other minor parties or electoral coalitions operating in Poland: Polish Coalition (Polish: Koalicja Polska), consisting of the Polish People's Party (Polish: Polskie Stronnictwo Ludowe) or the PSL, and a new movement, Kukiz' 15

The PSL is an agrarian-based, traditional Christian-democratic party whose support lies in rural Poland, especially the eastern part of Poland, where it directly competes with PiS for votes. The namesake of the PSL was one of the major political parties during both the inter-war period and era of communism in Poland. The PSL strongly advocates state protectionism in agriculture, and opposes abortion, same-sex civil unions, and euthanasia. Despite being very conservative on social issues, the PSL has found itself in several coalition governmentssurprisingly at times with the SLD and PO.

Waldemar Pawlak, the former leader of PSL, twice served as Prime Minister, briefly in 1992, and again from 1993 to 1995. Remerging once again from November 2007 to November 2012, Pawlak served as Deputy Prime Minister and the Minister of Economy. Pawlak remains as the only person who has held the office of Prime Minister twice since 1989.

Since 2015, PSL has been led by Dr. Władysław Kosiniak-Kamysz, who, at 34 years of age at the time when he was chosen as the PSL leader, is regularly mentioned as a potential opposition candidate in next year's presidential elections.

PSL's partner, Kukiz'15, is not registered as a political party, but as an "association." It is essentially a populist, anti-establishment movement (Stanley \& Czesnik, 2018), led by former punk rock star Paweł Kukiz. The group is composed of a disparate collection, including members of far-right groups, who were elected as MPs on the Kukiz' 15 ticket in 2015.

The Polish Coalition supports holding public referenda in order to gauge public support for creating laws-a specific demand of Kukiz. The Polish Coalition wants to end the taxation on pensions, and to make social insurance voluntary for entrepreneurs, which would certainly further complicate an already overburdened pension system, which according to Goclowski and Iglewski (2016, "Pension savings are a ticking time-bomb in Poland, which has one of the lowest birth rates in the European Union and also faces a mounting burden of paying out state pensions to people who did not save enough under communism."

The Polish Coalition garnered $8.55 \%$ in the parliamentary elections, which entitled them to 30 seats in the Sejm. The PSL also secured three seats in the Senate, effectively denying PiS its Senate majority. 
3.5.1 Confederation Freedom and Independence (Polish: Konfederacja)

Confederation is a far-right, "Eurosceptic" party, which brings together the National Movement (Polish: Ruch Narodowy), a nationalist group, and the followers of various right-wing libertarians (see Vasilopoulou, 2018). Its three main leaders are highly controversial figures on the Polish political scene, having variously expressed antiSemitic, Islamophobic, and decidedly misogynistic views. Confederation pledges to eliminate the income tax in Poland, as well as to make social insurance voluntary. (Social insurance is currently obligatory for all Polish students, business owners, and those who are formally employed in the Polish economy.) Confederation has adopted several political positions on the right, including opposition to Poland adopting the euro as its currency, opposing accepting migration from outside of the European Union, and opposing what it terms as the "LGBT and gender ideology." Confederation has also pledged to liberalize gun access, to "protect" Poland from Jewish restitution claims, and to strengthen Christian values and the traditional family model.

Reflecting the serious right-bent of Polish electoral politics, the 2019 election proved to be major success for Confederation, as it received $6.81 \%$ of the votes and gained 11 seats in the Sejm. Also reflecting the philosophy of the extreme right in Poland, one of its leaders summed up its main policies as: "We don't want Jews, homosexuals, abortion, taxes and the European Union." Janusz Korwin-Mikke, Confederation's leader, announced plans to introduce an "anti-LGBT law" that would "ban LGBT" from Poland, although Korwin-Mikke, a staunch opponent of the European Union, has at the same time "been associated with support for Putin's Russia" (Bachrynowski, 2015). Confederation will also put forward measures to further restrict abortion (Grzymala-Busse, 2016) and to prevent "the Holocaust industry" from using a new American law to profit from Jewish property restitution in Poland (see Wozniak, 2018). Sharon (2019) noted that "following the October (2019) parliamentary elections in Poland in which the Confederation Liberty and Independence won 6.8 percent of the vote, legislation was proposed which would ban and even criminalize the restitution of or compensation for heirless property." Grzegorz Braun, the Confederation's probable nominee in the next presidential election recently stated that "Jews have waged war against the Polish nation, and the whole Christian world, for centuries" (Sharon, 2019).

\section{Observations and Conclusions}

Curry (2014, p. 235) has correctly observed that "Poland was the first and one of the most successful transitions from a centralized communist state to a liberal, more Western-style democracy. During the European economic crisis, Poland's economy maintained one of the highest growth rates in the European Union. Its political system stabilized." The transition, at times, has not been an easy one (Hunter \& Ryan, 2006). Curry (2014, p. 235) further noted that "the Polish political system has been a 'work in progress' for years, changing its constitution and laws in response to what did and did not work. As a result, Poland went from an uneasy coalition of former communist leaders, Solidarity activists, and experts in 1989, to a system in which the former the right and then the former communists battled for power, and finally, by the end of the first two decades of democracy, to a stable system with two dominant parties close to the center and a number of smaller parties." Curry's comments were possibly correctly in 2014 - but events after 2015 may have changed this calculus, as Polish politics has taken a decided turn to the right. It will be important to monitor events closely in Poland to see which path Poland continues on. Will it be further liberalization in consort with other members of the European Union or will Poland embark on a path that further separates it from her European partners and roots?

\section{REFERENCES}

Ascherson, N. (2016). The assault on democracy is dangerous for the Poles and all Europe. The Guardian. Available: https:/www.theguardian.com/commentisfree/2016/jan/17/poland-rightwing-government-eurussia-democracy-under-threat (January 17, 2016).

Bachrynowski, S. (2015). Between Europe and Russia: The foreign policy of Janusz Korwin- Mikke's new right in Poland. The Polish Quarterly of International Affairs, 24(2): 135-144.

Balcer, A., Buras, P., Gromadzki, G., \& Smolar, E. (2016). Change in Poland, but what change? Assumptions of Law and Justice party foreign policy. The Stefan Batory Foundation: 1-19. Available: www.batory.org.pl/upload/files/Programy operacyjne/Otwarta Europa/Change in Poland.pdf

Casey, A. (2015). What does the Polish president actually do? Krakow Post. Available: http://www.krakowpost.com/9331/2015/05/what-does-the-polish-president-actually-do (May 8, 2015).

Chan, K. K-L. (2007). Poland at the crossroads: The 1993 general election. Europe-Asia Studies, 47(1): 123-145.

Chapman, A. (2017). Pluralism under attack: The assault on press freedom in Poland. Freedom House. Available: https://freedomhouse.org/report/special-reports/assault-press-freedom-poland (July 3, 2017)

Cienski, J. (2019). Donald Tusk won't run for Polish president. Politico. Available: https://www.politico.eu/article/donald-tusk-polish=president/ (November 5, 2019).

Curry, J.L. (2014). Poland: the politics of "God's playground," in Wolchik, S.L., \& Curry, J.L., eds., Central and Eastern European politics: From communism to democracy: 235-263. Latham, Md.: Roman \& Littlefield.

Dorrien, G. (2019). Social democracy in the making: Political and religious roots of social democracy. New Haven, 
Conn.: Yale University Press.

Engelberg, S. (1990). Poland elects Walesa president in landslide. New York Times: 1. Available: https://ww.nytimes.com/1990/12/10/world/poland-elects-walesa-president-in-landslide.html (December 10, 1990).

Fafara, A. \& Kleczkowska, A. (2015). How to attain the golden age- the role of the Balcerowicz plan in the successful transformation of Poland in the 1990s. Romanian Journal of Society and Politics, 10(2): 60-78.

Gabryszak, R. (2019). The evolution of the positions on special social issues of major political parties in Poland. Comparative analysis of the election programs of the Platforma Obywatelska (Civic Platform) and Prawo i Sprawiedliwosc (Law and Justice) from 2007, 2011 and 2015. Political Science Review, 24(4): 96-108.

Goclowski, M., \& Iglewski, J. (2016). Poland announces big shakeup in pension system. Reuters. Available: https://www.reuters.com/article/Poland-pensions-idUSL8N19Q134

Grabowski, W. (2019). Determinants of voting results in Poland in the 2015 parliamentary elections. Analysis of spatial differences. Communist and Post-Communist Studies, 52(4): 331-342.

Granat, M., \& Granat, K. (2019). The constitution of Poland: A contextual analysis. Oxford, U.K.: Hart Publishing.

Grzymala-Busse, A.M. (2002). Redeeming the communist past: The regeneration of communist parties in East Central Europe. Cambridge, U.K.: Cambridge University Press.

Grzymala-Busse, A.M. (2016). Why would Poland make its already strict abortion draconian? Washington Post. Available: https://www.washingtonpost.com/news/monkey-cage/wp/2016/04/18/why-would-poland-makeits-already-strict-abortion-law-draconian/?utm_term=ca257c333052 (April 18, 2016).

Harper, J. (2019). Poland's ruling party pledges pre-election minimum wage spike. Deutsche Welle (DM). Available: https://p.dw.com/P/3PIO (September 18, 2019).

Hunter, R.J. (2010). Katyn: Old issues threaten Polish-Russian economic and political relations,

European Journal of Social Sciences, 17(2) (Online): 288-ff. Available: https://www.scimagojr.com/journalsearch.php?q=89410\&tip=sid

Hunter, R.J., \& Domanska, M. (2016). Europe's poster child to Europe's problem child. Issues in Economics and Business, 2(1): 15-27).

Hunter, R.J., \& Lozada, H., R. (2019). Solidarity at Forty: Memories and influences on contemporary Poland: Does Solidarity still matter? European Journal of Business and Management, 11(23): 92-112.

Hunter, R.J., \& Ryan, L.V. (1998). From autarchy to market: polish economics and politics, 1945-1995. Westport, Conn.: Praeger.

Hunter, R.J., \& Ryan, L.V. (2006). A retrospective analysis and future perspective" Why was Poland's transition so difficult? The Polish Review, LI(2): 147-171.

Hunter, R.J., \& Ryan, L.V. (2009). Poland in 1989: Enter Tadeusz Mazowiecki and the creation of the Balcerowicz Plan. Research Journal of International Studies, 11: Article 4 (Online) (July 2009).

Hussein, J., Cottington, J. Nowicka, W., \& Kismodi, E. (2018). Abortion in Poland: Politics, progression and regression. Reproductive Health Matters, 26(52): 11-14.

King, L. (2017). In Poland, a right-wing populist, anti-immigrant government sees an ally in Trump. L.A. Times. Available: https:/www.latimes.com/world/la-fg-poland-trump-2017-story.html (July 5, 2017).

Kosicki, P.H. (2016). Poland turns right. Commonweal, 143(12): 10-11.

Kovacs, K., \& Scheppele, K.L. (2018). The fragility of an independent judiciary: Lessons from Hungary and Poland-and the European Union. Communist and Post-Communist Studies, 51(3): 189-200.

Kowalczyk, K. (2012). The Catholic Church in Poland as an entity influencing parliamentary elections (19892010). Polish Political Science Year Book, 41: 472-485.

Krygier, M. (2017). The rule of law after communism: Problems and prospects in East-Central Europe. London: Routledge.

Lewis, P.G. (2007). Poland and Eastern Europe: Perspectives on party factions and factionalism. Democratization, 2(1): $102-124$.

Lykoshina, L. (2015). From Gdansk to Brussels: Study of a political portrait of Donald Tusk. Contemporary Europe: Social and Political Research Journal, 1: 56-68. Available: http:// www.sov-europe.ru/2015/1/tit12.pdf

Marchuk, M.I. (2018). Legislative power in the Republic of Poland. Law and Safety, 71(4). Available: http://pb.univd.edu.ua//indexphp/PB/article/view/226

Marvin, T. (2010). Shock therapy: What we can learn from Poland. Prospect Journal. Available: https://prospectjournal.org/2010/11/11/shock-therapy-what-we-can-learn-from-poland/ (November 11, 2010).

Millard, F. (1994). The shaping of the Polish party system, 1989-93. East European Politics and Societies and Cultures, 8(3): 467-494.

Mishtal, J. (2015). The politics of morality: The church, the state, and reproductive rights in postsocialist Poland. Athens, Ohio: Ohio University Press. 
O’Dwyer, C., \& Vermeersch, P. (2016). From pride to politics: Niche-party politics and LGBT rights in Poland, in Slootmaekers, K., Touquet, H., \& Vermeersch, P., eds, The EU enlargement and gay politics: 123-145. Switzerland: Springer.

Ostrowski, K. (2019). The decline of power and its effects on democratization: The case of the Polish United Workers Party, in Lamentowicz, W., Ostrowski, K., Perczynski, M., \& Volten, P., eds, Eastern Europe and democracy. New York, New York: Institute for East-West Security Studies, Westview Press.

Pronczuk, M. 2019). A short guide to the Polish political scene. Notes from Poland. Available: https://notesfrompoland.com/2019/11/13/a-short-guide-to-the-polish-political-scene/

Ramet, S.P. (2016). The Catholic Church in Polish history. New York, New York: Palgrave Macmillan US.

Roache, M. (2019). Poland is holding massive pride parades. But how far have LGBTQ rights really come? Time. Available: https://time.com/5619660/lgbt-rights-poland/ (July 3, 2019).

Rzegocki, M., \& Partyka, J. (2017). Wealth redistribution won't solve Poland's demographic crisis. Acton. Available: https://acton/org/publications/transatlantic/2017/02/17/wealth-redistribution-wont-solve-Polanddemographic-crisis (February 17, 2017).

Sakowicz, M. (2017). Rebirth of local governments in Poland: 25 years of decentralization reform, in Ruano, J. \& Profiroiu, eds, The Palgrave handbook of decentralisation in Europe: 327-352. Switzerland: Palgrave Macmillan Cham:

Sauer, Natalie. (2018). Poland's coal miners: 'EU climate proposals terrify us.' Climate Change News. Available: https://www.climatechangenews.com/2018/09/24/poland-coal-miners-eu/ (September 24, 2018).

Scislowska, M. (2017). Polish president signs 1 of 3 contested laws on judiciary. Daily Herald. Available: https://www.dailyherald.com/article/20170725/news/307259989 (July 25, 2019).

Sharon, J. (2019). Poland's toxic property restitution debate fueling antisemitism-analysis. The Jerusalem Post. Available: $\quad$ https://www.jpost/Diaspora/Antisemitism/Polands-toxic-property-restitution-debate-fuelingantisemitism-analysis-610526 (December 12, 2019).

Sleszynski, P. (2006). How did Lech Kaczynski win the presidential election in 2005: A study of the electoral geography. Czasopismo Geograficzne: 61-82.

Stanley, B., \& Czesnik, M. (2018). Populism in Poland, in Stockemer, D., ed., Populism around the world: A comparative perspective: 67-87. Switzerland: Springer.

Sulek, A. (2007). The Polish United Worker's Party: From mobilisation to non-representation. Soviet Studies, 42(3): 499-511.

Szelewa, D. (2016). Killing ‘unborn children'? The Catholic Church and abortion law in Poland since 1989. Social \& Legal Studies, 25(6): 741-764.

Taylor, D. (2019). US to waive visa requirements for Polish citizens. Travel Market Report. Available: https://www.travelmarketreport.com/articles/US-to-Waive-Visa-Requirements-for-Polish-Citizens

Underwood, K. (2017). Poland has brought back the Sunday shopping ban. Trumpet Brief. Available: https://www.thetrumpet.com/16666-poland-has-brought-back-the-sunday-shopping-ban (December 19, 2017).

Vasilopoulou, S. (2018). The radical right and euroskepticism, in Rydgren, J., ed., The Oxford handbook of the radical right: 122-140. New York: Oxford University Press.

Wozniak, G.E. (2018). Facts and myths on restitution of property in Poland. Loyola of Los Angeles International and Comparative Law Review, 11: 331-350.

Wyrzykowski, M. (2018). Rule of law: European Commission v. Poland, in Hatje, A., \& Tichy, L., Verlagsgesselcchaft, N., eds, Liability of member states for the violation of fundamental values of the European Union: 169-200. Baden-Baden: Nomos.

Zuk, P. (2017). Non-alternative reality? On the misery of the left in Eastern Europe: The case of Poland. Journal of Contemporary Central and Eastern Europe, 25(1): 63-84.

Zuk, P., \& Zuk, P. (2019). Dangerous liaisons between the Catholic Church and state: The religious and political alliance of the nationalist right with the conservative church in Poland. Journal of Contemporary Central and Eastern Europe, 27(2-3): 191-212.

APPENDIX I

A CHRONOLOGICAL BIBLIOGRAPHY OF ARTICLES ON POLISH ECONOMICS, FINANCE, AND POLITICS BY RICHARD J. HUNTER AND COLLEAGUES

The Management Perspective on Poland's Economic Crisis and Recent Attempts at Reform, The Polish Review: 31(4): 299-313 (1986).

United States Policy Towards Poland: Options and Perspectives, Polish Studies Newsletter: 5-6 (January 1988).

Solidarity's Program for Economic Reform and the Current State of the Polish Economy, in Solidarity Lives (Leonard Polakiewicz, ed.), University of Minnesota Press (1989).

Uwaga! (Watch Out!): Opportunities and Pitfalls for an American Doing Business in Poland, with Leo V. Ryan, 
DePaul University, The Polish Review, 36(3): 345-361 (1991).

The Polish Experiment in Democracy and in a Free Market: Its Importance for Eastern and Central Europe, with Leo V. Ryan, DePaul University, Mid-Atlantic Journal of Business, 28(3): 231-234 (December 1992).

Management, Legal and Accounting Perspectives: Privatization in Poland, with John Northrop, Wright College, Chicago, Ill., The Polish Review, 38(4): 407-420 (1993).

Update on the Polish Economy, The Sarmatian Review, XIV(2): 244 (April 1994).

Out of Communism to What?: The Polish Economy and Solidarity in Perspective, with Andrew Hrechak, Seton Hall University, and Leo V. Ryan, DePaul University, The Polish Review, 39(3): 327-344 (1994).

Legal Aspects of the Transformation Process in Poland: Business Association Forms, with Artur Nowak, Adam Mickiewicz University, Poznan, Poland, and Leo V. Ryan, DePaul University, The Polish Review, 40(4): 387 407 (1995).

An Update on the Polish Legal System: Special Rules for Foreign Participation, with Leo V. Ryan, DePaul University, The Polish Review, 42(3): 339-348 (1997).

Prospects for the Polish Economy in 1999-2000, with Leo V. Ryan, DePaul University, The Sarmatian Review, XIX(3): 659-662 (September 1999).

Reform of the Polish Tax System Triumph of Politics over Policy? with Robert Shapiro, Seton Hall University, International Tax Journal, 26(4):79-85 (Fall 2000).

The Challenge of Political and Economic Change in Poland and Central and Eastern Europe, with Leo V. Ryan, DePaul University, International Journal of Value-Based Management, 13: 97-107 (2000).

Update on the Polish Economy, with Leo V. Ryan, DePaul University, The Polish Review, 45(4): 445-450 (2000).

Economic Transformation Through Foreign Direct Investment in Poland, with Leo V. Ryan, DePaul University, Journal of Emerging Markets, 6(2): 18-36 (Summer 2001).

Poland and the EU: The Final Chapter Before Accession, with Leo V. Ryan, DePaul University, The Sarmatian Review, XXII(2): 957-959 (April 2003).

Foreign Direct Investment in Poland, with Robert E. Shapiro, Seton Hall University, and Leo V. Ryan, DePaul University, The Polish Review, 48(3): 303-316 (2003).

Taxes, Development, and Economic Transformation, with Robert E. Shapiro, Seton Hall University, and Leo V. Ryan, DePaul University, International Tax Journal, 29: 1-21 (Fall 2003).

Trade and Economic Transformation in Poland, with Leo V. Ryan, DePaul University, Global Economy Journal, III(2-4): 163-177 (2004).

Legal Considerations in Foreign Direct Investment, with Robert E. Shapiro, Seton Hall University and Leo V. Ryan, DePaul University, Oklahoma City University Law Review, 28(2\&3): 851-872 (Summer/Fall 2003/04).

Privatization and Transformation in Poland, with Leo V. Ryan, DePaul University, The Polish Review, 49(3): 919943 (2004).

An Update on the Polish Economy, with Leo V. Ryan, DePaul University, The Sarmatian Review, XXV(1): 10901092 (January 2005).

A Primer on the National Bank of Poland: A Central Institution in the Transformation Process, with Leo V. Ryan, DePaul University, European Journal of Economics, Finance and Administrative Sciences, 1(1): Art. 1 (Online) (June 2005).

A Transitional Analysis of the Polish Economy: After Fifteen Years, Still a "Work in Progress, with Leo V. Ryan, DePaul University, Global Economy Journal, 5(2): Art. 6 (Online) (2005); Reprinted in Economic Research Division of the Federal Reserve Bank of St. Louis, available: http://www.ideas.repec.org/a/bpj/glecon/v5y2005i2n6.html

A Comprehensive and Contextual Review of Polish Taxation in 2005, with Robert E. Shapiro, Seton Hall University and Leo V. Ryan, DePaul University, International Tax Journal, 31(4): 23-36 (Fall 2005).

A Retrospective Analysis and Future Perspective: Why Was Poland's Transition So Difficult? with Leo V. Ryan, DePaul University, The Polish Review, LI (2): 147-171 (2006).

Transition in the Polish Economy, with Leo V. Ryan, DePaul University, in Developmental Entrepreneurship: Adversity, Risk, and Isolation (Craig Galbraith and Curt Stiles, eds.), Kidlington, Oxford, U.K.: JAI/Elsevier: 71-87 (Fall 2006).

John Paul II and the World's Poor, with Hector R. Lozada, Seton Hall University, in His Holiness Pope John Paul II: A Commemorative Volume of Essays (Charles Kraszewski, ed.), New York: PIASA Press: 43-58 (Fall 2006).

An Update and Analysis of the Polish Economy, with Leo V. Ryan, C.S.V., DePaul University, Sarmatian Review, XXVII(3): 1341-1342 (September 2007).

What is the Current State of the Polish Economy? with Leo V. Ryan, C.S.V., DePaul University, The Post Eagle: 2 (August 29, 2007).

A Field Report on the Background and Processes of Privatization in Poland, with Leo V. Ryan, DePaul University, Global Economy Journal, 8(2): Article 5 (Online) (2007). 
The Ten Most Important Economic and Political Events Since the Onset of the Transition in Post-Communist Poland, with Leo V. Ryan, DePaul University, The Polish Review, LIII(2): 183-216 (2008).

An Interim Report on the Polish Economy, with Leo V. Ryan, C.S.V., DePaul University, Sarmatian Review, XXVIII (3): 1418-1421 (September 2008).

The Legacy and Prospects of Polish Privatization, with Leo V. Ryan, DePaul University, International Research Journal of Finance and Economics, 21: 142-148 (2008).

Poland, the European Union, and the Euro: Poland's Long Journey to Full European Integration, with Leo V. Ryan, DePaul University, Global Economy Journal, 9(2): Article 6 (Online) (2009).

Poland in 1989: Enter Tadeusz Mazowiecki and the Creation of the Balcerowicz Plan, with Leo V. Ryan, DePaul University, Research Journal of International Studies, 11: Article 4 (Online) (July 2009).

Poland and the Euro, with Leo V. Ryan, DePaul University, Sarmatian Review, 29(3): 1491-1493 (September 2009).

The Battle Over the Deed to St. Stanislaus Bishop and Martyr Church in New York City: A Landmark Court Case, with Anne M. Gurnack and Renee Bradley, University of Wisconsin-Parkside, Polish American Studies, LXVII(1): 45-56 (Spring 2010).

Katyn: Old Issues Threaten Polish-Russian Economic and Political Relations, European Journal of Social Sciences, 17(2) (Online) (2010).

Polish Election 2010: Possible Political and Economic Implications (An Optimistic Scenario), with Leo V. Ryan, DePaul University, The Sarmatian Review, XXXI(1): 1547-1549 (January 2011).

Biographical Entries for Helena Rubenstein, Barbara (Piasecka) Johnson, Stephen Wozniak, Tadeusz Sendzimir, Max Factor, with Hector R. Lozada, Seton Hall University In Polish-American Encyclopedia (James Pula, ed.) (Jefferson, N.C.: McFarland Press): 111-112; 212-213; 462; 478-479; 553-554 (February 2011).

Reflections in Twenty Years of Political and Economic Change in Poland, with Leo V. Ryan, DePaul University, Global Economy Journal, 11(1): 1-15 (Spring 2011).

The Polish Economy in 2010: A Retrospective View Looking Towards 2011, with Leo V. Ryan, DePaul University, International Journal of Humanities and Social Science, 1(1): 65-69 (July 2011).

An Update on Polish Foreign Direct Investment: The Story of Intrall Rus: A Case Study on Transformation, with Leo V. Ryan, DePaul University, International Journal of Academic Research in Business and Social Science, 2(1): 594-603 (January 2012).

A Polish Hybrid: The Limited Joint-Stock Partnership or LJSP, International Tax Journal, 38(3): 41-46 (May-June 2012).

Poland and the European Union, with Leo V. Ryan, DePaul University, International Journal of Academic Research in Economics and Management Sciences, 1(3): 122-130 (June 2012).

The Legal, Economic and Political Context of Lustration in Poland: Is Lustration a Necessary or Inevitable Part of Political and Economic Transformation? with Leo V. Ryan, DePaul University, and Robin-O'Brien Lichtenstein, Seton Hall University, European Journal of Academic Research, 1(3): 148-170 (2013).

Foreign Direct Investment 2013-2014: Destination Poland? An Update and Appraisal, with Leo V. Ryan, DePaul University, Research in Applied Economics, 5(4): 13-21 (2013).

Poland, The European Union, and the Euro, with Leo V. Ryan, DePaul University, The Sarmatian Review, XXXIII(1): 1728-1730 (January 2013); Reprinted in The Post Eagle: 2, 10 (January 16, 2013).

Economic Transformation and Privatization, with Leo V. Ryan, DePaul University, Warsaw East European Review, III: 37-52 (2013).

Poland in 2014: Twenty Five Years of Transition: Is Poland A Normal Country? with Leo V. Ryan, DePaul University, Global Journal of Human Social Science, 14(1): 1-8 (Online) (2014).

Comprehensive and Contextual View of Polish Taxation in 2014, with Leo V. Ryan, DePaul University, International Tax Journal, 40(2): 27-35 (March-April 2014).

A Report from Poland on the Economy, with Leo V. Ryan, DePaul University, The Sarmatian Review, XXXIV(3): 1879-1873 (September 2014).

Ten Years of Polish Membership in the European Union: An Update and an Appraisal, with Leo V. Ryan, DePaul University, Quarterly Journal of Business Studies, 1(4): 30-140 (2014).

A Retrospective on Poland's Foreign Trade: Changes in the Regime Accomplished in the Light of Poland's History of Central Planning and its Membership in COMECON, The Early Years, with Leo V. Ryan, DePaul University, Advances in Management and Applied Economics, 5(4): 1-20 (2015)

Poland: A Country Study- "Europe's Poster Child to Europe's Problem Child, with Marta Domanska, MBA Candidate, Seton Hall University, Issues in Economics and Business, 2(1): 15-27 (June 2016)

Charting a New Path for Poland or Turning Its Back on More Than A Quarter Century of Progress? Archives of Business Research, 5(2): Article 3, 20-30 (February 2017).

Poland's Sustained "March to a Market Economy": The Choice Between Competing Visions and Values, Research in World Economy, 9(1): 61-76 (May 2018).

Poland and FDI: Pathway to Development or Flashpoint to Conflict within the European Union, Global Journal 
of Economics and Finance, 3(1): 1-17 (February 2019).

Solidarity at Forty: Memories and Influences on Contemporary Poland: Does Solidarity Still Matter? with Hector Lozada, Seton Hall University, European Journal of Business and Management, 11(23): 97-112 (2019).

APPENDIX II -PRIME MINISTERS OF POLAND (1989-)

$\underline{\text { Solidarity Electoral Action (AWS) Law and Justice (PiS) Civic Platform (PO) }}$

\begin{tabular}{|c|c|c|c|c|c|c|}
\hline № & Name & Took office & Left office & Party & Coalition partner(s) & $\begin{array}{l}\text { Term in } \\
\text { office }\end{array}$ \\
\hline 1 & $\frac{\text { Tadeusz }}{\text { Mazowiecki }}$ & $\begin{array}{l}24 \text { August } \\
1989\end{array}$ & $\begin{array}{l}4 \quad \text { January } \\
1991\end{array}$ & $\begin{array}{l}\text { Solidarity } \quad \text { Citizens' } \\
\frac{\text { Committee }\left(\mathrm{KO}^{\prime} \mathrm{S}^{\prime}\right)}{\text { Democratic Union (UD) }}\end{array}$ & $\underline{\text { ZSL-PZPR }}$ & $\begin{array}{l}1 \text { year, } \\
133 \text { days }\end{array}$ \\
\hline 2 & $\frac{\text { Jan Krzysztof }}{\underline{\text { Bielecki }}}$ & $\begin{array}{l}4 \text { January } \\
1991\end{array}$ & $\begin{array}{l}6 \text { December } \\
1991\end{array}$ & $\begin{array}{l}\text { Liberal Democratic } \\
\text { Congress (KLD) }\end{array}$ & $\underline{\mathrm{ZChN}}-\underline{\mathrm{PC}}-\underline{\mathrm{SD}}$ & 336 days \\
\hline 3 & Jan Olszewski & $\begin{array}{l}6 \text { December } \\
1991\end{array}$ & 5 June 1992 & Centre Agreement (PC) & $\frac{\text { ZChN-PSL.PL- }}{\text { PChD }}$ & 182 days \\
\hline 4 & Waldemar Pawlak & 5 June 1992 & 10 July 1992 & Polish People's Party (PSL) & None & 35 days \\
\hline 5 & Hanna Suchocka & 11 July 1992 & $\begin{array}{l}26 \text { October } \\
1993\end{array}$ & Democratic Union (UD) & $\begin{array}{l}\text { KLD-ZChN-PChD- } \\
\text { PPPP-PSL.PL-PPG- } \\
\text { SLCh }\end{array}$ & $\begin{array}{l}1 \quad \text { year, } \\
107 \text { days }\end{array}$ \\
\hline 6 & Waldemar Pawlak & $\begin{array}{l}26 \text { October } \\
1993\end{array}$ & $\begin{array}{ll}7 & \text { March } \\
1995 & \end{array}$ & Polish People's Party (PSL) & $\underline{\text { SLD-UP-BBWR }}$ & $\begin{array}{l}1 \text { year, } \\
132 \text { days }\end{array}$ \\
\hline 7 & Józef Oleksy & $\begin{array}{ll}7 & \text { March } \\
1995 & \end{array}$ & $\begin{array}{l}7 \quad \text { February } \\
1996\end{array}$ & Social Democracy (SdRP) & $\underline{\mathrm{PSL}}$ & 337 days \\
\hline 8 & $\begin{array}{l}\text { Włodzimierz } \\
\text { Cimoszewicz } \\
\end{array}$ & $\begin{array}{l}7 \quad \text { February } \\
1996\end{array}$ & $\begin{array}{l}31 \text { October } \\
1997\end{array}$ & Social Democracy (SdRP) & $\underline{\mathrm{PSL}}$ & $\begin{array}{l}1 \quad \text { year, } \\
266 \text { days }\end{array}$ \\
\hline 9 & $\underline{\text { Jerzy Buzek }}$ & $\begin{array}{l}31 \text { October } \\
1997\end{array}$ & $\begin{array}{l}19 \text { October } \\
2001\end{array}$ & $\begin{array}{l}\text { Solidarity Electoral Action } \\
\underline{\text { (AWS) }}\end{array}$ & $\frac{\mathrm{UW}-\mathrm{SKL}}{\mathrm{PPChD}}-\underline{\mathrm{ZChN}}-$ & $\begin{array}{l}3 \text { years, } \\
353 \text { days }\end{array}$ \\
\hline 10 & Leszek Miller & $\begin{array}{l}19 \text { October } \\
2001\end{array}$ & 2 May 2004 & $\begin{array}{l}\text { Democratic Left Alliance } \\
\text { (SLD) }\end{array}$ & $\underline{\mathrm{UP}-\mathrm{PSL}}$ & $\begin{array}{l}2 \text { years, } \\
196 \text { days }\end{array}$ \\
\hline 11 & Marek Belka & 2 May 2004 & $\begin{array}{l}31 \text { October } \\
2005\end{array}$ & $\begin{array}{l}\text { Democratic Left Alliance } \\
\text { (SLD) }\end{array}$ & UP & $\begin{array}{l}1 \text { year, } \\
182 \text { days }\end{array}$ \\
\hline 12 & $\begin{array}{l}\text { Kazimierz } \\
\text { Marcinkiewicz } \\
\end{array}$ & $\begin{array}{l}31 \quad \text { October } \\
2005\end{array}$ & 14 July 2006 & $\underline{\text { Law and Justice (PiS) }}$ & $\underline{\text { SRP-LPR }}$ & 256 days \\
\hline 13 & $\begin{array}{l}\text { Jarosław } \\
\underline{\text { Kaczyński }}\end{array}$ & 14 July 2006 & $\begin{array}{l}16 \\
\text { November } \\
2007\end{array}$ & $\underline{\text { Law and Justice (PiS) }}$ & $\underline{\mathrm{SRP}}-\underline{\mathrm{LPR}}$ & $\begin{array}{l}1 \quad \text { year, } \\
125 \text { days }\end{array}$ \\
\hline 14 & Donald Tusk & $\begin{array}{l}16 \\
\text { November } \\
2007\end{array}$ & $\begin{array}{l}22 \\
\text { September } \\
2014\end{array}$ & Civic Platform (PO) & $\underline{\text { PSL }}$ & $\begin{array}{l}6 \text { years, } \\
310 \text { days }\end{array}$ \\
\hline 15 & Ewa Kopacz & $\begin{array}{l}22 \\
\text { September } \\
2014\end{array}$ & $\begin{array}{l}16 \\
\text { November } \\
2015\end{array}$ & Civic Platform (PO) & PSL & $\begin{array}{l}1 \text { year, } \\
55 \text { days }\end{array}$ \\
\hline 16 & Beata Szydło & $\begin{array}{l}16 \\
\text { November } \\
2015\end{array}$ & $\begin{array}{l}11 \text { December } \\
2017\end{array}$ & Law and Justice (PiS) & None & $\begin{array}{l}2 \text { years, } \\
25 \text { days }\end{array}$ \\
\hline 7 & $\frac{\text { Mateusz }}{\text { Morawiecki }}$ & $\begin{array}{l}11 \text { December } \\
2017\end{array}$ & Incumbent & $\underline{\text { Law and Justice (PiS) }}$ & None & $\begin{array}{l}2 \text { years, } \\
50 \text { days }\end{array}$ \\
\hline
\end{tabular}

